\title{
АГНАТЫ И РЫБЫ В МЕЛКОВОДНЫХ ФАЦИЯХ ВЕНЛОКА И ЛУДЛОВА СЕВЕРНОИ ПРИБАЛТИКИ
}

Распределение силурийских позвоночных в разнофациальных отложениях Прибалтики рассмотрено в ряде работ (Мярсс, Әйнасто, 1978; Кальо и др., 1983, 1986; Курик, Мярсс, 1986; Мярсс, 1986; Märss, 1989). В них главное внимание обращено на ареал распространения и условия захоронения агнат и рыб в осадках. Следующий этап изучения экологии и тафономии силурийских позвоночных заключается в выяснении зависимости их расселения от органогенных построек (биогермов, биостромов). Настоящая статья и посвящена этим вопросам, причем изучению подвергнуты все мелководные шельфовые фации рассматриваемой территории.

Материалом анализа послужили образцы из 20 разрезов скважин и 7 обнажений Западной Эстонии, островов Сааремаа и Қихну и северной части Курземского полуострова. Распространение позвоночных изучено в узких стратиграфических интервалах начиная от яагарахуского горизонта в середине венлока и кончая паадласким горизонтом в нижней половине лудлова. Распределение позвоночных по крупным таксономическим группам показано на литологических колонках буровых разрезов и обнажений (рисунок).

С конца раннего венлока в Прибалтийском бассейне стала проявляться тенденция к регрессии (Эйнасто, 1986). Регрессия благоприятствовала развитию органогенных построек, которые в венлоке-лудлове Прибалтики были представлены по меньшей мере на девяти стратиграфических уровнях (Klaamann, Einasto, 1982). В обмелевших бассейнах могли образовываться сравнительно небольшие органогенные постройки, в основном на очень подвижноводной отмельной полосе карбонатного шельфа, а также на смежных более тиховодных участках открытого и закрытого шельфа (Әйнасто, устное сообщение, 1989).

В среднем венлоке, во время образования в и ль с ан д и с к и х сл ое в яагарахуского горизонта, наступил первый максимум рифообразования (Klaamann, Einasto, 1982). Полоса биогермов протягивалась с о-ва Готланд через о-в Сааремаа на материковую Әстонию. Биогермы были сложены в основном строматопоратами Vikingia tenue в западной части и строматолитами в восточной части. Кораллы в них встречались реже (Klaamann, Einasto, 1982). Породы из этого стратиграфического уровня в большинстве случаев сильно доломитизированы (разрезы скв. Эйкла508, Везику-507, Кипи и Кингисепп), отчего остатки позвоночных здесь весьма редки. В разрезе Лаймъяла и клиффа Панга чешуи Thelodus sp. и Acanthodei gen. et sp. ind. встречены в битуминозных доломитах, которые Р. Әйнасто интерпретирует как отложения закрытого шельфа, образовавшиеся в за-и межрифовом пространстве.

Следующий уровень с органогенными постройками прослежен в м а а 3 и с к и х слоя х яагарахуского горизожта. Они имеют облик биостром, в которых кораллы играют главную роль, а строматопораты - второ-

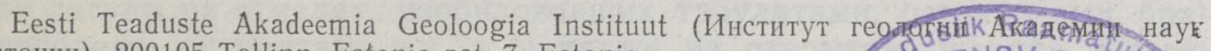
Әстонии). 200105 Tallinn, Estonia pst. 7. Estonia.

(C) Eesti TA Toimetised. Geoloogia, 1991

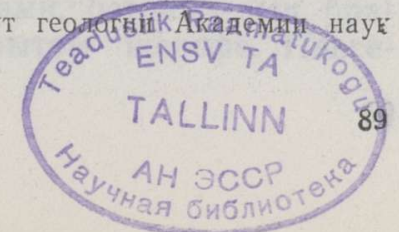




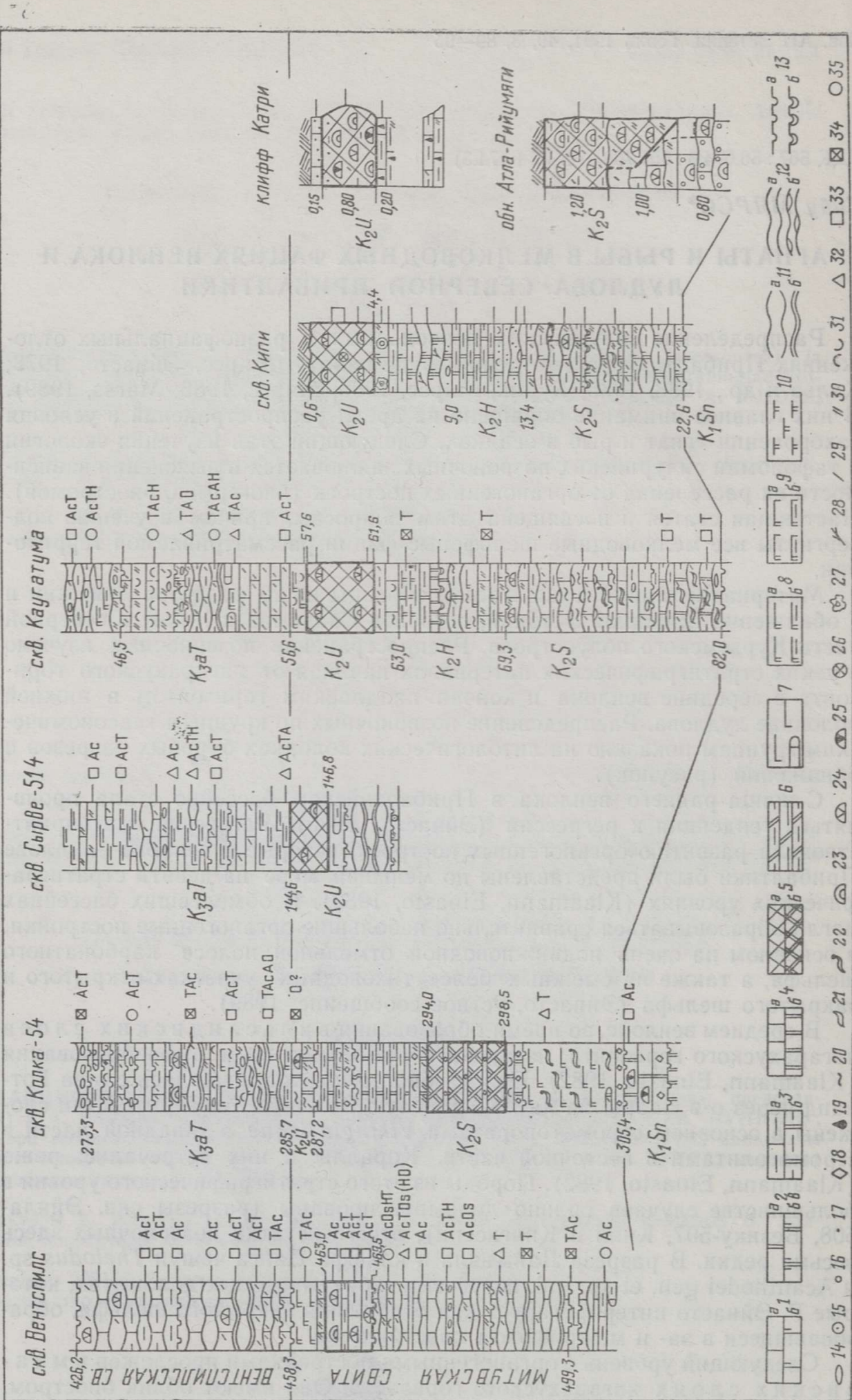


Распределение позвоночных в лудловских разрезах скважин и обнажений Северной Прибалтики. Литологические колонки буровых разрезов составлены Р. Эйнасто, обнажений - X. Нестором.

Условные обозначения. Черточками на правой стороне литологической колонки отмечены глубины опробования: - пустые образцы, АсТН - образцы содержат остатки агнат и рыб (на первом месте - преобладающая группа), Т - телодонты, Н - гетеростраки, O - остеостраки, A - анаспиды, Ac - акантоды, Os - остеихтиды; 1 известняк чистый (а) и доломитовый (б), 2 - доломит чистый (а), известковый (б) и известковистый (в), 3 - известняк (a) и доломит (б) глинистый, 4 - известняк (a) и доломит (б) иловый скрыто-микрокристаллический, 5 - биогермные известняки (a) и доломиты (б), 6 - доломит эвриптеровый, 7 - мергель с комками известняка, 8 домерит чистый (a) и глинистый (б), 9 - домерит известковистый доломитовый (a) и известковистый глинистый (б), 10 - глины доломитистые, 11 - комковатые текстуры (a), они же с прослоями глины (б), 12 - волнисто-слоистые (а) и линзовидные (б) текстуры, 13 - простые (а) и сложного строения (б) поверхности перерыва, 14 - гальки, 15 - оолиты, 16 - псаммит, 17 - сгустки, 18 - обломки неокатанные, 19 - примесь рассеянного органического вещества, $20-$ ходы илоедов, $21-$ ходы илоедов сложного строения, 22 - они же пиритизированные, 23 - строматопораты, 24 - табуляты массивные, 25 - табуляты ветвистые, 26 - криноидеи, 27 - онколиты, 28 известковые водоросли, 29 - мелкий детрит, 30 - крупный детрит, 31 - цельные створки остракод, брахиопод, 32 - чешуи рыб хорошей сохранности, 33 - чешуи средней сохранности, 34 - сломанные чешуи, 35 - окатанные чешуи.

степенную (Klaamann, Einasto, 1982). В крупно- до мелкодетритистых известняках, отнесенных к предбиогермной полосе отмели (см. Радионова, Эйнасто, 1986), обнаружен телодонт Loganellia taiti (разрезы скв. Везику-507 и Кингисепп). Тот же самый вид встречен в эвриптерусовых доломитах (разрез скв. Сакла), которые считаются лагунными отложениями. В более открытоморских отложениях (разрез скв. Охесааре) в комковатых глинистых мелкодетритистых известняках телодонты L. taiti и Thelodus laevis установлены вместе с самой ранней в Палеобалтике анаспидой Birkeniida sp. B. На о-ве Готланд чешуи L. taiti найдены в заполнении лакун Cystihalysites cavernosus (Клааманн, 1982).

Начиная с тагавереского в ремен и на рассматриваемой территории распространяется практически монотаксонное коралловое сообщество Riphaeolites lamelliformis. В силурийском море этот вид заселял в основном лагуны или забарьерную часть отмели (Клааманн, 1982). Так же беден комплекс агнат. В позднетагавереской лагуне обитали только телодонты L. taiti и Thelodus sp. (разрезы скважин Кипи, Везику-507, Паадла, Сакла, Сымера-1, Әйкла-508), в более глубоководной части бассейна (в глинистых мергелях разреза скв. Колка-54) им сопутствовали и акантоды Gomphonchus aff. sandelensis. Акантоды, по некоторым данным (Heyler, 1962), происходят из примитивной группы акул. Современные акулы считаются океаническими пелагическими рыбами, которые могут обитать и вблизи погруженных коралловых рифов, над ними и в лагунах атоллов (Наумов и др., 1985).

По Э. Клааманну и Р. Эйнасто (Klaamann, Einasto, 1982), в Восточной Прибалтике отсутствуют органогенные постройки, выделяемые на о-ве Готланд на трех стратиграфических уровнях: Халла «в», слои Мульде, средняя часть слоев Клинтеберг. Предполагается (Р. Эйнасто, устное сообщение, 1989; Кальо, Юргенсон, 1977), что в роотсикюлаское время биогермная полоса проходила южнее о-ва Сааремаа на двух уровнях. В роотсикюласком горизонте установлены отложения, обогащенные алевритом, что свидетельствует о значительном привносе терригенного материала (Юргенсон, 1981). Характерно переслаивание лагунных эвриптерусовых доломитов (верхневийтаские и верхневезикуские слои) и отмельных биоморфно-детритовых доломитов (нижневийтаские и нижневезикуские слои).

В $\mathrm{p}$ анневи й т аское в рем я позвоночные обитали в забарьерной лагуне, на отмелях, изобиловавших табулятами, остракодами, брахиоподами, онколитами и т. д., а также на открытом шельфе. Повсе- 
местно (разрезы скв. Лаймъяла-515, Сакла, Кипи, Сымера-1, Охесааре, Колка-54) преобладали телодонты, за исключением разреза Кихну-526, где обнаружены только акантоды. Последние присутствуют и в осадках отмельной и открытошельфовой зон (разрезы скв. Охесааре и Колка-54).

В позд не в й т а ской л агун е (разрезы скв. Везику-507, Кипи, Каугатума, Охесааре и обнажение Везику) встречены только различные бесчелюстные: телодонты, остеостраки и анаспиды. Преобладание бесчелюстных над челюстноротыми характерно для всего венлока (за исключением депрессионной фациальной зоны в роотсикюлаское время).

Во время образования ранневезикуских слоев в бассейне господствовали специфические отмельные условия, неблагоприятные для обитания агнат и рыб. Слои изобилуют породообразующими водорослево-бактериевыми структурами (онколитами и строматолитами), которые содержат материал псаммитовой и псефитовой размерности. Остатков позвоночных в породе не отмечается. Впервые они обнаружены в типичных лагунных отложениях близлежащих разрезов (скв. Везику-507 и Кипи). Основываясь на материале по разрезу р. Омнутах (Норильский р-н) и на современных данных, Ю. И. Тесаков с соавторами (1986) высказали мнение о том, что венлок-лудловские строматолитовые постройки образовывались на широком мелководном шельфе в полосе приливной равнины, а иногда и на себхе. В работах по биологии современных морей одной из главных причин малочисленности организмов в водорослевых биотопах считается та, что в относительно мелководных лагунах тропических морей вода зачастую перегрета, обеднена кислородом и биогенными элементами, т. е. для обитания морских животных она неподходяща. Для некоторых же водорослей (напр., Halimeda), наоборот, такие условия оптимальны (Калиненко, Медведев, 1980). Таким образом, при анализе условий обитания рыб в Палеобалтийском бассейне, который в силурийском периоде, как известно, находился в тропической зоне, следует учитывать повышенную температуру воды и, в ряде случаев, недостаток кислорода. Нельзя также игнорировать возможность пониженной солености вод в лагунах роотсикюлаского времени (Эйнасто, 1968).

Вследствие изменения условий с расширением поздневезикус ко й л а гун ы увеличилась и площадь, занятая агнатами (разрезы скв. Лаймъяла-515, Сымера-1 и Каармизе). Сходная картина в распространении позвоночных имела место также в позднетагавереское и поздневийтаское время, когда к обитавшим в лагуне агнатам добавились со стороны открытого моря и акантоды.

После максимума регрессии в конце венлока в роотсикюлаское время наступила кратковременная трансгрессия в раннем лудлове, которая вскоре вновь сменилась регрессивной фазой. Море находилось в тех же районах, что и во второй половине венлока. В паадлаское время на севере Прибалтики наступил второй максимум рифообразования, прекратившийся в результате обмеления бассейна в химмистеское время (Кальо, Юргенсон, 1977).

В раннепаадласких, с реднесаувереских (=рийумягиских) би огерм ах важную роль играли табуляты Thecia swindereniana и субальвеолиты, а также богатый комплекс строматопорат с Densastroma podolicum (Klaamann, Einasto, 1982). Остатки позвоночных встречаются как в предбиогермной зоне, так и в забиогермной. Позвоночные представлены агнатами: телодонтами, остеостраками и анаспидами. Самым характерным телодонтом для отмельно-биогермной полосы является Phlebolepis ornata (обнажения Кандла, Кярла, Когула, разрезы скв. Oхесааре, Техумарди, Сымера и Варбла?). В кроне чешуй P. ornata имеются резкие угловатые, относительно высокие ребрышки, препятствовавшие быстрому перемещению рыб этого вида. Учитывая это 
обстоятельство, можно предположить, что $P$. ornata населяли в саувереское время в основном биогермную полосу. В собственно биогермах их остатки не сохранились. Образцы из обнажения Атла-Рийумяги не содержат никаких остатков рыб. На берегу моря, у мыса Роопа обнажаются небольшие скопления кораллов, представляющие как бы зачаточные (эмбриональные) биогермы. В породе, заполняющей пространство между колониями табулят, найдены единичные чешуи акантодов. В разрезе скв. Колка-54 установлены доломитизированные кавернозные породы, неблагоприятные для сохранения фосфатных остатков позвоночных (см. рисунок).

В позднепаадлаское, удувереское время строматопораты, табуляты и сирингопориды образовывали маломощные биостромы. Собственно биогермные породы не содержат остатков позвоночных (см. рисунок, клифф Катри, разрезы скв. Кипи, Каугатума, Сырве-514). В разрезе скв. Вентспилс на гл. $464-470$ м в митувской свите вскрыты глинистые известняки со строматопоратами и кораллами предбиогермной (?) полосы, содержащие как агнаты, так и рыбы. Для этого времени характерно первое появление в Палеобалтике представителей гетеростраков и остеихтид. Челюстноротые стали преобладать над бесчелюстными сначала в глубоководных (разрезы скв. Вентспилс и Сырве-514), а затем, постепенно, и в мелководных фациях бассейна (скв. Каугатума).

Из возможных причин отсутствия скелетных элементов агнат и рыб в собственно биогермных породах можно отметить две. Первая - в условиях высокоэнергетических обстановок, существовавших на биогермных отмелях, скелетные остатки агнат и рыб, которые представляли собой зерна песчаной и гравийной размерности (диам. 0,5-1,5 мм), выносились течением за пределы этих отмелей и захоронялись в смежных (предили забиогермных) фациях (ширина пояса рийумягиских биогермов достигала 1 -2 км). Вторая - в современных коралловых биотопах известны животные (некоторые раки, моллюски и т.д.), питающиеся преимущественно мертвыми организмами, в том числе и рыбами (Наумов и др., 1985). Не исключено, что некрофаги обитали и в силурийском море.

\section{Выводы}

1. Нашли подтверждение ранее выявленные закономерности в распределении силурийских позвоночных. Агнаты и рыбы обитали преимущественно в неритической области моря (в современной прибрежной части водоемов с глубинами до 200 м) и, не столь многочисленно, в пелагиали над глубоководными участками.

2. Опираясь на результаты изучения биологии современных морей, которые свидетельствуют об исключительном богатстве рифовых биоценозов (так, по Д. В. Наумову и др., 1985, в коралловых биоценозах известно около 2800 видов коралловых рыб), можно полагать, что рыбы заселяли и силурийскую биогермную полосу. В пользу этого, в частности, говорят единичные чешуи, найденные в биогермных «ловушках», в лакунах кораллов.

3. Небольшие скопления кораллов, которые можно рассматривать как начальную стадию образования биогермов, содержат чешуи позвоночных.

4. Сформировавшиеся биогермы и биостромы, как правило, не содержат остатков агнат и рыб. Причины их отсутствия в венлокских-лудловских биогермах связаны прежде всего с палеогидродинамическими и палеобиологическими факторами. Чешуи и другие фрагменты выносились за пределы биогермной полосы активными волновыми течениями, а мертвые рыбы уничтожались некрофагами. 
5. Вполне правдоподобным представляется предположение о том, что обитанию рыб в водорослевых биоценозах не благоприятствовали повышенная температура воды и, как следствие этого, нарушенный химизм среды (недостаток кислорода, ненормальная соленость).

6. Гибель рыб или их миграция в другие слои воды могли быть связаны с бурным развитием синезеленых водорослей, способных продуцировать сами или выделять при разложении токсичные для планктонных животных вещества (Горюнова, Демина, 1974; Мануйлова, 1962).

\section{ЛИТЕ РА Т У РА}

Горюнова С. В., Демина Н. С. 1974. Водоросли - продуценты токсических веществ. Москва, Наука.

Калиненко В. В., Медведев В. С. 1980 . Литолого-фациальные особенности карбонатных отложений тропических островов Тихого океана. - Тр. Ин-та океанол. AH CCCP, 90, 117-140.

Кальо Д. Л., Вийра В. Я., Клааманн Э. Р., Мянниль Р. П., Мярсс Т. И., Нестор В. В., Нестор Х. Э., Рубель М. П., Сарв Л. И., Эйнасто Р. Э. 1983. Экологическая модель силурийского бассейна Восточной Прибалтики. - В кн.: Проблемы экологии фауны и флоры древних бассейнов. Москва, Наука, 43-61.

Кальо Д. Л., Вийра В. Я., Мярсс Т. И., Нестор В. В. 1986. Сообщества нектона, нектобентоса и планктона (рыб, бесчелюстных, конодонто-носителей, граптолитов, хитинозой) силура Восточной Прибалтики. - В кн.: Теория и опыт экостратиграфии. Таллинн, Валгус, 127-136.

Кальо Д. Л., Юргенсон Э. А. 1977. Фациальная зональность силура Прибалтики. - В кн.: Фация и фауна силура Прибалтики. Таллинн, ИГ АН ЭССР, $122-148$.

Клааманн Э. Р. 1982. Сообщества табулят (поздний венлок и лудлов острова Готланд). - В кн.: Сообщества и биозоны в силуре Прибалтики. Таллинн, Валгус, $35-50$.

Курик Э. Ю., Мярсс Т. И. 1986. Крупные фациальные изменения в силуре-девоне и их отражение на ихтиофауне. - В кн.: Тезисы докл. XXXII сессии ВПО. Таллинн, 46.

Мануйлова E. Ф. 1962. Влияние синезеленых водорослей на развитие зоопланктона. Бюл. Моск. об-ва испыт. природы. Отд. биол., 67, вып. 1, 128.

Мярсс Т. И. 1986. Позвоночные силура Әстонии и Западной Латвии. Таллинн, Валгус.

Мярсс T., Эйнасто P. 1978. Распределение вертебрат в разнофациальных отложениях силура Северной Прибалтики. - Изв. АН ЭССР. Геол., 27, 1, 16-22.

Наумов Д. В., Пропп М. В., Рыбаков С. Н. 1985. Мир кораллов. Ленинград, Наука.

Радионова Э. П., Эйнасто Р. Э. 1986 . Водорослевые сообщества венлока и лудлова Эстонии и их связь с фациями. - В кн.: Теория и опыт экостратиграфии. Таллинн, Валгус, 163-185.

Тесаков Ю. И., Предтеченский Н. Н., Хромых В.Г., Бергер А. Я., Боголепова О. К., Волкова К. Н., Заславская Н. М., Курушин Н. И., Лучинина В. А., Москаленко Т. А., Сенников Н. В., Шешегова Л. И., Ядренкина А. Г. 1986. Фауна и флора силура Заполярья Сибирской платформы. Новосибирск, Наука.

Эйнасто Р. Э. 1968. Фациальные и палеогеографические условия образования эвриптеровых доломитов (силур Прибалтики). - В кн.: Генезис и классификация осадочных пород. Междунар. геол. конгр., XXIII сессия. Докл. сов. геол. Проблема 8. Москва, Наука, 68-74.

Эйнасто Р. Э. 1986. Основные стадии развития и фациальные модели силурийского краевого бассейна Балтики. - В кн.: Теория и опыт экостратиграфии. Таллинн, Валгус, $37-54$.

Юргенсон Э. А. 1981. Зональное распределение терригенного материала в силурийских отложениях Северной Прибалтики. - В кн.: Условия образования осадочногө чехла и структуры Прибалтики. Рига, Зинатне, 121-128.

Heyler, D. 1962. Les Acanthodiens et le problème de l'aphétohyoidie. - Coll. Intern. Centre Nat. Rech. Sci., 104, 39-47.

Klaamann, E., Einasto, R. 1982. Coral reefs of Baltic Silurian (structure, facies relations). - In: Ecostratigraphy of the East Baltic Silurian. Tallinn, Valgus, $35-41$.

Märss, T. 1989. Vertebrates. - In: A Global Standard for the Silurian System. M. G. Bassett, C. H. Holland (eds.). Cardiff, $284-289$.

Представил Д. Қальо 


\section{AGNAADID JA KALAD PÖHJA-BALTIKUMI WENLOCKI JA LUDLOW' MADALAVEELISTES FAATSIESTES}

Kinnitust leidsid siluri selgroogsete jaotumuse seaduspärasused: agnaadid ja kalad eelistasid elada mere neriitilises vööndis, mis praegustes meredes hõlmab rannalähedase, kuni $200 \mathrm{~m}$ sügavusega mere osa. Nad asustasid ka süvamere pelagiaali, kuid nende leiud vastavatest setetest on harvad.

Toetudes nüüdisaegsete riffide rikkalikule elustikule, võib arvata, et ka siluri rifi biotsönoosi kuulusid kalad. Selle kinnituseks võivad olla üksikute soomuste leiud biohermsetes püünistes, näit. koralli lakuunides. Samuti võib neid leida korallide kogumikes, mis kujutavad endast arengu algstaadiumis peatuma jäänud biohermseid moodustisi. Tühjaks osutusid väljakujunenud biohermide setted. Samuti ei sisalda soomuseid sinivetikate (tsüanofüütide) moodustistest (onkoliitidest, stromatoliitidest) rikkad setted. Kalade puudumine vetikate biotoobis võib olla tingitud kõrgenenud veetemperatuurist, vähesest hapnikusisaldusest, vetikate poolt vette eritatud mürkidest või ka ebanormaalsest soolsusest vastavas mereosas. Agnaatide ja kalade skeletiosade puudumise võimalikeks pōhjusteks biohermikivimis võivad olla eelkõige paleohüdrodünaamilised (lainetus kandis soomused yööndist välja), aga ka paleobioloogilised tegurid (nekrofaagid, näit. mõned molluskid ja vähilaadsed kasutasid kalade laipu toiduks).

\section{Tiiu MARRS}

\section{AGNATHANS AND FISHES IN SHALLOW FACIES OF THE NORTH-EAST BALTIC WENLOCK AND LUDLOW}

This work confirms the distribution pattern of Silurian vertebrates: agnathans and fishes preferred to habitate the neritic belt of the sea. In the modern seas this belt corresponds to the onshore parts with the depth of up to $200 \mathrm{~m}$. The Silurian agnathans and fishes dwelled also in the offshore pelagic zone, but their finds from the corresponding sediments are rare.

The fauna of the recent reefs allows us to suppose that the biocoenosis of the Silurian reefs included also fishes. This may be proved by the presence of single scales in biohermal traps, e. g. in coral lacunae. They can be found also in small accumulations of corals treated as the initial stage of the development of bioherms. Scales do not occur in the rocks of the "mature" bioherms. Neither were the remains found in the sediments rich in cyanophycean formations (stromatolites, oncolites). This may refer to a higher temperature, insufficiency of oxygen, presence of poisonous substances secreted into water by algae, or abnormal salinity of the corresponding part of the sea. The lack of skeletal particles of agnathans and fishes in bioherms is probably caused mainly by paleohydrodynamic (scales were transported out of the belt by wave activity) and paleobiological (dead fishes were used as food by necrophagous organisms, e. g. molluscs and crustaceans) factors. 